\title{
Digital Transformation Modelling in the Context of Slowbalization
}

\author{
Iluta Arbidane ${ }^{1}$, Hanna Purii ${ }^{2 *}$, Abdukhakim Mamanazarov ${ }^{3}$, Serhii Hushko ${ }^{2}$ and Volodymyr Kulishov ${ }^{2}$ \\ ${ }^{1}$ Rezekne Academy of Technologies, 115 Atbrivosanas aleja, Rezekne, LV-4601, Latvia \\ ${ }^{2}$ State University of Economics and Technology, 16 Medychna Str., Kryvyi Rih, 50005, Ukraine \\ ${ }^{3}$ Tashkent Branch of M. V. Lomonosov Moscow State University, Tashkent 100060, Uzbekistan
}

\begin{abstract}
The article studies modern concepts and theories of digital transformation of society, analyzes structural changes in the economy during the fourth industrial revolution, presents different views of experts on the expected positive results of Industry 4.0 in the context of globalization. The authors suggest models and correlate increment rate dynamics with the information globalization index in the world and individual countries, and identify trends in the development of digital transformation in the context of slowbalization. The study considers possible consequences and risks of Industry 4.0 and ways to level them, outlines the priority areas of digital transformation to ensure high competitiveness of national economies in the period of slowbalization.
\end{abstract}

\section{Introduction}

Modern society exists in the world where information technology is integrating into all spheres of human life. The digital revolution has introduced a new way of thinking, social behaviour, building an ecosystem, and doing business, the latter changing to new standards of strategic positions in various sectoral spheres of public life and real economy and adapting to innovative conditions at an unpredictable rate.

Global labour division according to individual countries' specialization in producing certain goods and services is the determinant of developing world economic relations and one of the most important trends in the world economic progress. The countries taking advantage of opportunities and benefits of participating in global labour division experience positive rates of their economic and social growth.

In terms of digital transformation, this period of social development is characterized as the Fourth Industrial Revolution, or Industry 4.0. Transition to the Industry 4.0 concept shows that in the future such business processes as supply of raw materials, development and delivery of goods to consumers and their maintenance will be carried out through digitalization of services. That is why, the study of the world's digital transition to Industry 4.0 is of great topicality.

\section{Brief analysis of the researches}

In scientific circles, prospects and directions of smart technology development and digitalization have recently been paid much attention to due to the constant global transformations of economic systems. Theoretical research on the issues of digital transformation and, in particular, Industry 4.0 focuses on certain aspects of the Fourth Industrial Revolution, namely: economic problems of introducing Industry 4.0 and its impact on the development of a state economic sector; peculiarities of Industry 4.0 application to state regulations; transformation of TNC strategies in the context of the fourth industrial revolution; political consequences of Industry 4.0 introduction and others.

Regardless of the significant number of publications on this issue, the dynamic and rapid digital transformation of economic systems daily creates new challenges and risks of Industry 4.0 for society and scientists requiring the development of relevant tools to level them.

\subsection{Role and extent of Industry 4.0 development in different countries}

Adapting to innovations, digital transformation has reached a new level while its integration into all social spheres is becoming mandatory. Such countries as China, Great Britain, Singapore, New Zealand, Estonia, the UAE, Japan, and Israel are considered the leaders in digital technology development. When studying their experience, it is possible to identify advantages and disadvantages of social digitalization [1].

Industry 4.0 results in an increased amount of stored, processed and available knowledge associated with the array growth, namely: a set of approaches, tools and methods of processing structured and unstructured big data, a significant variety of human-perceived and effective results in the context of their continuous increase and distribution through numerous nodes of a computer network $[2,3,4]$.

\footnotetext{
* Corresponding author: puriy av@,kneu.dp.ua
} 
According to experts, the fourth technological revolution will deepen economic and social inequality leading in a short run to even greater stratification of population: technology owners and developers will receive excess profit, while low-skilled staff will earn meagre wages, and the middle class will literally disappear. However, after staff retraining, the situation will level off. Following the World Economic Forum (WEF), more than 5 million jobs will disappear as a result of the development of genetics, robotics and other technological changes. In total, about $47 \%$ of vacancies in the United States today are at risk of extinction due to changes associated with automation and transition to the digital environment. For example, $65 \%$ of today's schoolchildren will have brand new professions [5]. Robots and digital technology will form a new type of production, while technologies that combine physical, biological and digital worlds will form a new type of consumption. This will lead to even greater specialization of the service sector by creating specialized business platforms that will bring together certain groups of people in horizontal models of interaction. Goods and services will be high quality and cheap, but this can significantly reduce the cost of human labour.

New technologies will provide for implementing thoughts and ideas. However, they will increase the risks for society to be controlled by new tools via an overwhelming digital infrastructure and possible implantation of chips in human bodies to manage their consciousness. Many countries are now developing egovernment, e-procurement and other blockchain systems. Most likely mass decentralization of power will be possible as the state will not be the source of wealth. Developed will be the states able to adopt a new paradigm of development and change their regulatory mechanism, which should become flexible thanks to innovative technologies and be based on principles of tripartism (close cooperation of state, business and society) [6]. A state should adjust to an individual, nature and new technologies, not the opposite. The fourth technological revolution will also affect national and international security as interstate conflicts will be largely hybrid, and the boundaries between war and peace will be blurred. The fourth wave will change not only the space where a person lives, but also his/her personality: worldview, values, behaviour, habits, lifestyle, communication, consumption, time for work and rest, approaches to education, and success criteria.

Common features of all the four technological revolutions include development of science; use of new energy sources, materials; invention of machines and technologies; work organization; expansion of labour specialization; emergence of new industries, significant changes in transportation and communications; increase of urban population; changes in the structure of society, its values, style, and manner of interaction and behaviour [7]. Concurrently, all the unresolved problems of previous revolutions are carried over to the next ones and deepened significantly.
Thus, summarizing the comprehensive scale of Industry 4.0, it is possible to identify its main consequences (Table 1) [8-12].

Table 1. Consequences of Industry 4.0.

\begin{tabular}{|c|c|}
\hline $\begin{array}{l}\text { At the } \\
\text { global } \\
\text { econom } \\
\text { y level }\end{array}$ & $\begin{array}{l}\text { - a jump of labour productivity in processing } \\
\text { industries; } \\
\text { - creation of new markets and diminishment of } \\
\text { some traditional activities; } \\
\text { - formation of global centres of rapid industrial } \\
\text { growth; } \\
\text { - radical restructuring of the existing system of } \\
\text { the world labour division by reducing obsolete } \\
\text { elements of the technological chain of previous } \\
\text { systems, mainly in developing countries; } \\
\text { - reduction of the need for unskilled labour and } \\
\text { exacerbation of global unemployment. }\end{array}$ \\
\hline $\begin{array}{l}\text { At the } \\
\text { social } \\
\text { level }\end{array}$ & $\begin{array}{l}\text { - a sharp increase in the amount of scientific } \\
\text { and technical information, emergence of } \\
\text { fundamentally new approaches to its } \\
\text { processing and ways to manage hardware and } \\
\text { software tools for research and development; } \\
\text { - blurring of disciplinary and sectoral } \\
\text { boundaries in research and development, } \\
\text { interdisciplinary and convergent nature of } \\
\text { research; } \\
\text { - higher requirements to researchers' } \\
\text { qualifications, international competition for } \\
\text { talented highly-qualified employees and their } \\
\text { involvement in science, engineering, technical } \\
\text { entrepreneurship; } \\
\text { - compression of the innovation cycle: a } \\
\text { significant time reduction between acquisition } \\
\text { of new knowledge and creation of } \\
\text { technologies, products and services, their entry } \\
\text { into the market; } \\
\text { - a growing role of international standards }\end{array}$ \\
\hline $\begin{array}{l}\text { At the } \\
\text { individ } \\
\text { ual level }\end{array}$ & $\begin{array}{l}\text { - digital reality as for people's activity and } \\
\text { communication space affects their personal } \\
\text { level, namely: development of higher mental } \\
\text { functions, values, motivation, interaction } \\
\text { manner and behaviour }\end{array}$ \\
\hline
\end{tabular}

As a result of such digital transformation, various types of activity are transferred to the virtual dimension, this determining increased enthusiasm among the digital community leading to their worsened adaptability to the outer world and strained interaction with other types. At the same time, the manner of acting and communicating of the virtual world is transferred to the real-life one. As such, digital technologies expand and transform human abilities creating the basis for new realia. Using new digital technologies, a person creates objects of the secondary (multimedia) nature, which are easily 
transformed and controlled through communications, interaction, and exchange of multimedia products.

Under the Fourth Technological Revolution, information technology will be the main driver of development [13]. Nevertheless, society cannot avoid traditional manufacturing that, however, will take place in laboratories, data processing research companies, high-tech automated engineering plants, robotic shops, high-performance data centers, etc. In Ukraine, on the other hand, IT industry is traditionally contrasted with others; in particular, with mineral processing and agriculture, while in developed countries, they rely on technologies and actively implement them in the national economy. Therefore, the leaders of the "Global Innovation Index 2019" are Switzerland, Sweden, the USA, the Netherlands, Great Britain, Finland, Denmark, Singapore, Germany, Israel; in the post-Soviet space the best results are shown by Estonia (24th place), Armenia (33rd), Latvia (34th) and Lithuania (38th), then Russia (46th), Ukraine (47th place) and Moldova (58th). The worst are Belarus (72nd place) and Azerbaijan (84). Turkmenistan and Uzbekistan are not represented in the ranking. Kazakhstan is the 79th with its closest neighbours - Kyrgyzstan (90) and Tajikistan (100) that showed, according to international experts, lower results [14].

\subsection{Benefits and ambiguity of multiplying effects}

The development of digital transformation affects not only business efficiency, but also economic performance and preparedness for the future. Governments invest heavily in their digital economies to contribute to value creation and prosperity.

All-out digitalization has contributed to the rapid development of globalization, and global processes have led to rapid informatization of public communication. Therefore, under modern conditions, development of Industry 4.0 and globalization rate itself are significantly correlated with each other and generate a multiplying effect $[15,16]$.

However, in the recent decade, global economy has been experiencing a transition from total globalization to more constrained slow stabilization. Today's realia indicate growing tension between economic nationalism and globalization, which is becoming one of the determent trends at the threshold of the next decade [17].

Over the past four decades, ideas, products, money, and people have been crossing borders freely following globalization growth. This has led to rising income inequality. However, the integration rate has slowed markedly due to transition to domestic or local development and emergence of slowbalization. The close correlation between globalization and digitalization of society necessitates forecasting development of Industry 4.0 in the context of slowbalization of society.

In order to assess the degree of inclusion of individual countries in the process of globalization, four globalization indices are used to build a ranking of countries according to their degree of involvement in global flows: A.T. Keamey's globalization index, the KOF-globalization index, the CSGR globalization index and the Global Index. [1]. As such, the KOFglobalization index includes three dimensions of globalization: economic, political and social. The index is treated as a combined indicator that allows assessing the level of a country's integration in the world and comparing different countries by its components. All the countries being surveyed within the Index are assessed by 24 indicators combined into three main groups of global integration:

1) economic globalization includes the following indicators: the international trade volume; the level of international business activity; trade flows; international investment; tariff policy; international trade restrictions and taxes, and so on;

2) social globalization is expressed through such indicators as the level of cultural integration; the percentage of foreign population; international tourism; international personal contacts; the volume of telephone traffic, postal items, cross-border money transfers; information flows; development of information and communication infrastructure;

3) the third one - political globalization is characterized by the following indicators: membership in international organizations; participation in international missions (including the UN missions); ratification of international multilateral treaties; the number of embassies and other foreign missions in the country. The globalization level index is calculated as a sum of these components with the weight ratio of $36 \%, 38 \%$, and $26 \%$ respectively.

All countries under this investigation are ranked according to the Globalization Index, which indicates their place among other countries studied. The final value of the index from 0 to 100 points is obtained by evaluating 24 indicators combined into three components: globalization in the economic, social and political spheres. The higher the index value of the state is, the more it is involved in world processes (Fig. 1).

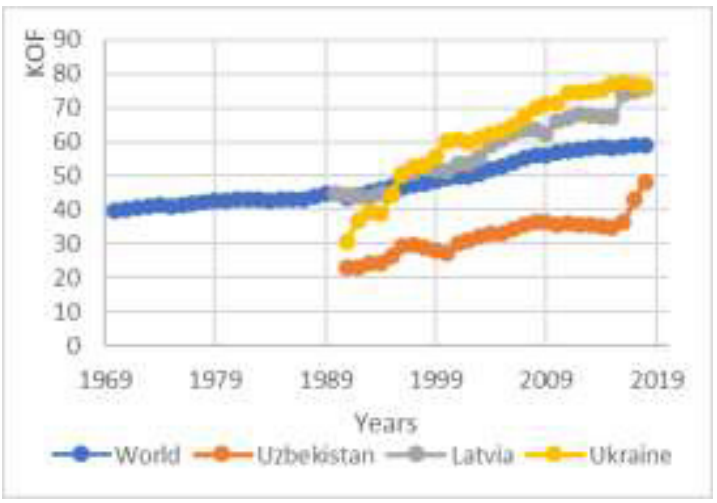

Fig. 1. Dynamics of the Globalization Index (KOF) in the world and some countries.

Globalisation has slowed from light speed to a snail's pace in the past decade [19]. This is caused by the following factors:

- first, transportation costs have been stabilized; 
- second, transnational companies have found that global expansion 'burns their money', while national competitors have advantages over them;

- third, trade tends to focus on the services difficult to sell abroad;

- fourth, Chinese production has become more independent and the need in parts import has reduced.

Nowadays, society is in the fifth period of digital transformation occasionally called slow stabilization or slowbalization. Trade tension is caused by the changes continuing since the financial crisis of 2008-2009. In comparison to the world GDP, cross-border investments, trade, bank loans and delivery chains are being cut or stagnating. Globalization is giving place to a new epoch of slowdown or slowbalization, concurrently there are limited sources for Industry 4.0 development. In the context of economic egoism of leading national economies, efficient use of digital communications, development of technological infrastructure and application of new technologies can be constrained by national boundaries (Fig. 2).

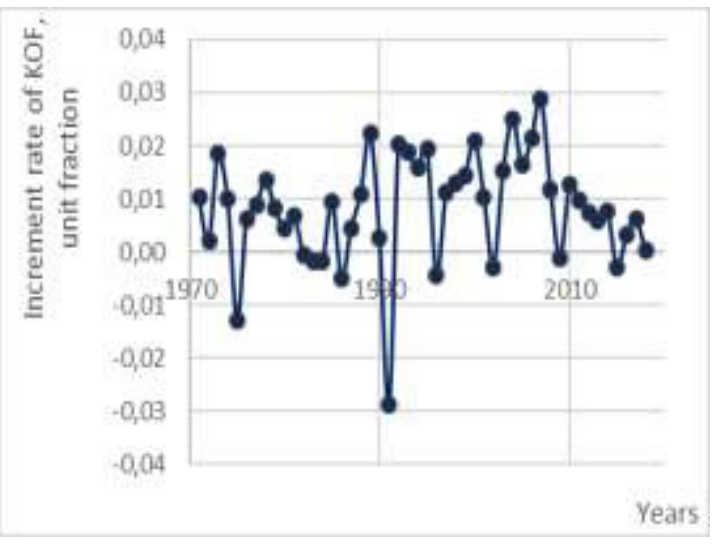

Fig. 2. Increment rate dynamics of the KOF Globalization Index, unit fraction.

Analysis indicates that the KOF Information Globalization level has also slowed down reaching its climax in 2008 (Fig. 3).

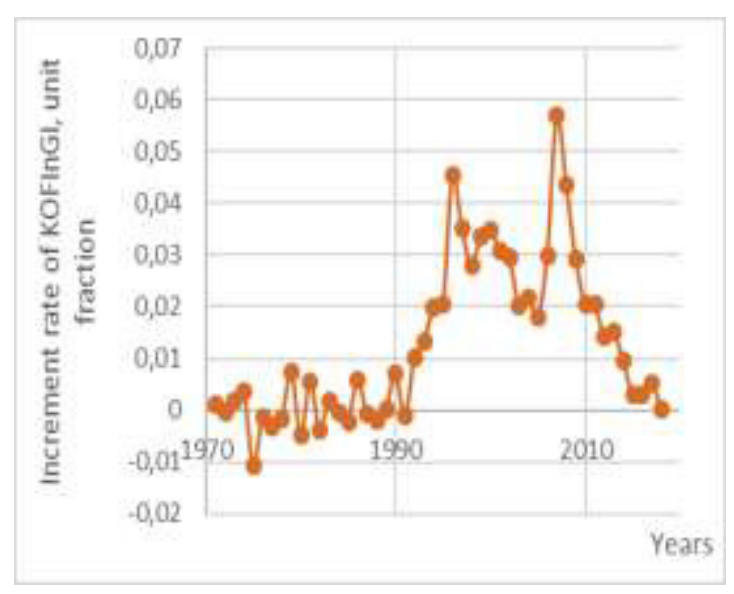

Fig. 3. Increment rate dynamics of the KOF Information Globalization Index, unit fraction.
Gradual reduction of increment rates of global information globalization reveals a current stage of decline in digitalization of society due to the law of marginal utility. That is why, after the decline stage a new wave of communication digitalization can be expected.

Analytical researches enable conclusions about stagnation both of the globalization index and the information globalization index in the world, this confirming the beginning of communicative slowbalization of national economies.

The authors studied density of interrelations between the analyzed global indices in 1970-2018 and those for some countries (Ukraine, Latvia and Uzbekistan) in 1991-2018 (Fig. 4).

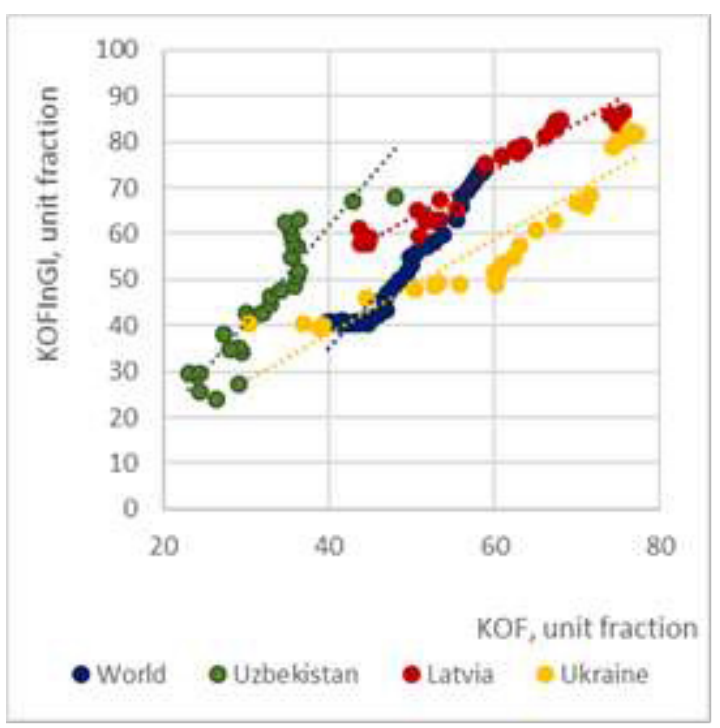

Fig. 4. Correlative dependencies between the KOF globalization index and the information globalization index (KOFInGI)

The analyzed dependencies are presented by equations with determination factors R2 (Table 2)

Table 2. Correlative dependencies between the KOF globalization index and the information globalization index in the world and in some countries.

\begin{tabular}{|l|l|c|}
\hline Country & $\begin{array}{c}\text { Correlation type of the } \\
\text { information globalization and } \\
\text { the globalization indices }\end{array}$ & $\mathbf{R}^{\mathbf{2}}$ \\
\hline World & $Y_{\text {World }}=1.9781 \mathrm{x}-44.16$ & 0.9602 \\
\hline Latvia & $Y_{\text {Latvia }}=1.0228 \mathrm{x}+12.446$ & 0.9399 \\
\hline Uzbekistan & VUzbekistan $_{\text {U }}=2.1181 \mathrm{x}-22.984$ & 0.8156 \\
\hline Ukraine & VUkraine $_{\text {Und }}=1.0292 \mathrm{x}-2.8499$ & 0.864 \\
\hline
\end{tabular}

High determination indices indicate that the obtained observations conform the models (Table 2), while the increased level of society's information communication ability is accompanied by the increased world globalization level.

Yet, further slowbalization can cause different consequences for Industry 4.0 development in different national economies. To model the determined dependencies, there are specified annual average 
increment rates of globalization indices in 2009-2018 (Table 3).

Table 3. The increment factor of globalization indices in 20092018 of the world and some countries.

\begin{tabular}{|l|c|}
\hline Country & The increment factor, unit fraction \\
\hline World & 0.00485 \\
\hline Latvia & 0.01816 \\
\hline Uzbekistan & 0.03032 \\
\hline Ukraine & 0.00872 \\
\hline
\end{tabular}

As is seen from Table 3, increment levels of the globalization indices vary, which is conditioned by the analyzed countries' internal and external space. In total, low rates of globalization increment in the world provide evidence for slowbalization beginning.

The KOF increment factors (Table 3 ) and determined correlations between the globalization and information globalization indices (Table 2) enable modelling forecast values of the information globalization (KOFInGI) in the world and some countries in 2025-2050 (Fig. 5).

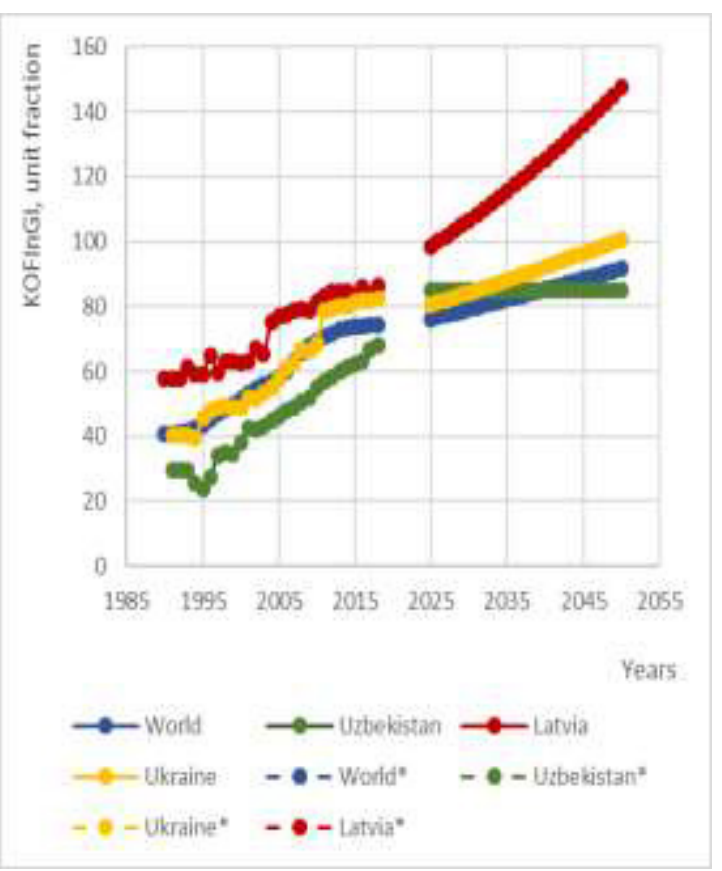

Fig. 5. Dynamics of actual and forecast values of dependency of the KOF globalization index and the information globalization index (KOFInGI) of the world and some countries.

The obtained modelling results indicate significant impacts of available digital potentials of each country's transformation at the beginning of slowbalization. Economic egoism of national economies can not only encourage Industry 4.0, but also become its digital constraint. That is why, the countries with a higher level of information globalization at the beginning of slowbalization (Latvia, Ukraine) will have rising development trends of Industry 4.0 and the economic situation will cause the rapid advance of informationcommunication technologies in these countries. On the contrary, In Uzbekistan, the society's digitalization level developed steadily constraining Industry 4.0 and this might cause decelerated rates of the country's information globalization.

Thus, the obtained results reveal ambiguous trends of Industry 4.0 development under slowbalization conditions.

For this reason, during the slowbalization period; on the national level, Industry 4.0 is to encourage high competitiveness of national economies by their prioritized areas of activity including:

- combining production and ICT;

- combining a client and production data;

- maximally using potential of mechatronic systems;

- managing production in an autonomous, flexible and efficient manner.

No doubt, digitalization provides a variety of advantages like numerous multiplying effects from including all the industrial chains into a single informational space. Yet, the impact of digitalization on society and economics is controversial due to some reasons:

- first, transition of economics to a new level, which is implemented by digitalization, leads to destruction of the older industrial system and welfare distribution, this characterizing digital technologies as 'undermining';

- second, introduction of new technologies is characterized by excessive optimism, i.e. a total effect from using digital dividends is much weaker than expected, in other words, there is a steady trend of reducing the world average economic rates of labour productivity with only $15 \%$ of enterprises' digitalization projects being successful;

- third, there is irregularity of distributing the positive effect from introduction of digital economy both among countries and population groups inside a country;

- fourth, digitalization is to a greater extent more profitable for trade companies and banks, while 'scattered' technologies (robotization, blockchain technology, neural networks, artificial intelligence, quantum virtual and augmented reality) used to optimize production cause reduction and elimination of jobs.

As to positive aspects, it should be noted that the digital space is becoming an environment for new generations allowing exploring the world in a new way and creating radically new research tools. Human creative potentials are also evident as when used along with digital, computer and information technologies, they make a person essentially incomplete and open to changes.

\subsection{Basic risks of Industry 4.0 and their levelling}

Along with numerous positive aspects of digital transformation, experts define some basic risks as well: vulnerability (unauthorized impacts, cyberterrorism) and illegal application of technology (video surveillance control, etc.);

- application of artificial intelligence, robotization, automation: increased social alienation caused by loss of jobs, elevated unemployment, social tension, mass surveillance, potential leakage of commercial secrets, etc.; 
- application of blockchain technology associated with vulnerable security of the blockchain system itself and the service infrastructure on its basis, irremovability of information in the network (inability to correct errors and change incorrectly input data), application of tokens as a tool of 'money washing', financing of terrorism;

- application of imported microelectronics. The basic part of software (software of operating systems and database control systems) and computer equipment used, for example in Ukraine, are brought from abroad. It is not impossible that they can contain special spy chips;

- application of cloud technologies and distributed calculations - dependency on reliability of the telecommunication system; dilution of responsibility for information security and reduced control because of its distribution among companies-users, an entity and a cloud platform's owner.

- Internet functioning stability;

- impacts on social conscience. Development of big data technologies, expansion of the network space, achievements in cognitive and behavioral sciences have conditioned appearance of effective methods aimed at implicit data collection and concealed control over group behaviour;

- increased complexity of business-models and lack of highly-qualified staff.

To level all the mentioned risks and apply Industry 4.0 potential to conserving basic principles of sustainable economic development, the society's cognitive paradigm should be oriented at:

- development of the cybersecurity system and the cyberpolice structure;

- formation of the most vital employment skills in future, namely: the elevated level of emotional intelligence; communicative ability; time management; technical skills; creativity and creative approaches to problem solution;

- introduction of the 'closed educational system' without using IT;

- professionals of the future (a solar/wind power technician, a software designer, a data analyst, a digital content manager, a digital security analyst, blockchain designer, an unmanned aircraft dispatcher, a 'smart house' designer, a 3D-print designer, an augmented reality designer, an advisor on personal life issues, an urban and farm economist, a genetic engineer, a personal education guide, an end-of-life manager, an avatar designer, an extinct species revival specialist.

- acquisition of experience in building an effective system of cross-cultural communication;

- formation of creative innovative thinking based on innovating technologies;

- introduction of environmental and energy education.

Thus, digital transformation of society and software will allow exploring the world in a new way and creating radically new research tools. Being an open system and transforming the world in the autopoetic communication process, human beings infinitely expand, transforming themselves and the environment.

\section{Conclusions and recommendations}

Rapid development of technologies to make modern life better, potential of fast communication connections with each continent; access to information and its fast perception, processing, transmission by mobile technical devices; the community's participation in power execution, opportunities to improve life standards, accelerated development of national minorities and national regions are positive consequences of digital transformation of society.

Development of digital technologies of doing business is accompanied with risks to inviolability of personal life and private data conservation. No limitations on mass media concentration may lead to mass conscience manipulations as well as state or criminal structures control over an individual. Thus, there are negative factors affecting social conscience in the information space.

Besides, there are also significant adverse effects of digitalization including time insufficiency for personal life; application of digital technologies for entertainment industries only and not as an educational or a business resource; 24-hour surveillance of human existence; constant pressure on an individual who has to get adapted to new technologies; rapid access to information causing its distortion and elimination.

The renovated world is noted for accelerated rates of 'digital dictatorship' expansion. If the world community does not start discussing current events as problems, humanity will have all the chances of losing their own identity, culture values, morals and ethics.

Business digitalization and digital transformations of the present day are limitless opportunities for innovative advances. This very fact is both a key advantage and a threat for people. Despite of the fact that computers are able to find an answer better, it is the human who asks the question.

\section{References}

1. Official site of the platform "Industry 4.0" (Federal Ministry of Economic Affairs and Energy. Federal Ministry of Education and Research, Germany, 2020). http://www.plattform/i40.de/

2. I.V. Tarasov, Industry 4.0: Concept \& Development. Business Strategies. (2018). doi:10.17747/2311-7184-2018-5-43-49

3. Big data and analytics for IBM Power Systems (IBM, 2020).

http://www.ibm.com/systems/ua/power/solutions/bi gdata/analytics/

4. B. Marr (Ed.). Index. In Big Data in Practice. (2016). https://doi.org/10.1002/9781119278825.inde $\mathrm{x}$

5. S. Voitko, A. Polishchuk, O. Tkachenko, Development of the defense and industrial complex on the basis of Industry 4.0. Political Science and Security Studies Journal, (2020). doi:10.5281/zenodo.4310124 
6. J.Marius Müller, Daniel Kiel and Kai-Ingo Voigt, What Drives the Implementation of Industry 4.0? The Role of Opportunities and Challenges in the Context of Sustainability. Sustainability, 2018). doi:10.3390/su10010247

7. R. Shevchuk, A. Melnyk, Mobile Cyberphysical System for Dynamic Display of Object Information on Digital Location. Scientific Bulletin of NLTU of Ukraine, (2017). doi:10.15421/40270436

8. Schwab K. The fourth industrial revolution. Cologny (Geneva Switzerland: World Economic Forum, 2016).

9. G. Maxton, J. Randers, In search of prosperity. Managing economic development to reduce unemployment, inequality and climate change. (Pabulum, Kyiv, Ukraine, 2017).

10. Ph. Steden, R. Kirchner. Industry 4.0 -Overview and Policy Implications. (German Advisory Group, Berlin Economics, 2018).

https://www.beratergruppeukraine.de/wordpress/wpcontent/uploads/2018/08/P B_06_2018_en.pdf.

11. L. O. Syhyda Industry 4.0 and its Impact on the Countries of the World. World Economy and International Economic Relations. (2018). doi:10.32782/2524-0072/2018-17-9

12. N. Kraus, K. Kraus, O. Marchenko, Digital economy and innovation-entrepreneurial university in the light of competitiveness. Efektyvna ekonomika, (2020). doi: 10.32702/2307-21052020.3.5

13. Li Guoping, Hou Yun, Wu, Aizhi, Fourth Industrial Revolution: technological drivers, impacts and coping methods. Chinese Geographical Science. (2017). doi: 10.1007/s11769-017-0890-x

14. Global Innovation Index (Cornell University, INSEAD, and the World Intellectual Property Organization, 2019), https://www.wipo.int/edocs/pubdocs/en/wipo_pub_gii_20 19.pdf Accessed 20 Jan 2021

15. S. Hushko, I. Mietule, K. Slyusarenko, N. Sheludiakova, Information Economy in the Context of Sustainable Development of Society and its Effect on TNC Activity. Scientific Journal of Polonia University. (2017). doi:10.23856/2406

16. T. Dołęgowski, S. Hushko, V. Kulishov, Problems of Instability of the World Economy Under Globalization. Society. Integration. Educatoin Proceedings of the International Scientific Conference. (2017). doi:10.17770/sie2017vol4.2280

17. N. Bahashova, H. Puriy, Integration of Ukraine into European Union in Globolizing World. Scientific Journal of Polonia University. (2017). doi:org/10.23856/2013

18. G. Savina, F. Haelg, N. Potrafke, J.-E. Sturm, The KOF Globalisation Index - Revisited. Review of International Organizations. (2019). doi:10.1007/s11558-019-09344-2
19. The Economist Newspaper and The Economist Group. Slowbalisation. The Economist. (The Economist Newspaper Ltd, 2019). 